\title{
Robust Application of the Arbitrage Pricing Theory and the Test for Volatility in the Stock Market: Evidence from Nigeria
}

\author{
Dada, Samuel Obafemi Kolapo, Funsho Tajudeen Mokuolu, Joseph Oluseye
}

Alabi, Kehinde Miracle

Department of Finance, Ekiti State University, Nigeria

\begin{abstract}
This study examined the presence of the arbitrage pricing theory as well as volatility in the Nigerian stock market between 1986 and 2018. The study used stock returns as the dependent variable and also used oil price, exchange rate, inflation rate, interest rate, industrial output and real gross domestic product as independent variables. The classical Ordinary Least Square revealed that industrial output has positive effect on stock returns in the short run while the ARDL revealed that inflation has a negative effect on stock returns in the long run. Also, the ARCH and GARCH technique revealed that volatility is evidently high and persistent while the Granger Causality test revealed a unidirectional causality running from inflation and interest rates to stock returns and a bi-directional causal relationship between exchange rate and stock returns. Therefore, it can be concluded that the APT is valid in the Nigerian stock market. Hence, it was recommended that short term investors should pay more attention to the industrial output as diversification to other sectors like agriculture is highly encouraged. Also, the government should adopt policies such as substantial tax reliefs, grants and import substitution strategies to boost industrial output to ensure substantial stock returns in the short run. Invariably, such attempt to boost industrial output will increase competition and efficiency and reduce cost in the economy, coupled with other strategies such as floor and ceilings of macroeconomic rates, inflation will be reduced and become relatively stable to keep stock returns attractive.
\end{abstract}

Keywords: Asset Pricing, Arbitrage Pricing, Stock Returns, Macroeconomic Volatility

JEL Classification Codes: G1, O4, E3, E6

DOI: $10.7176 / \mathrm{RJFA} / 12-4-01$

Publication date: February $28^{\text {th }} 2021$

\subsection{INTRODUCTION}

The financial system is the impetus of every economy, this system encompasses regulatory institutions and other players within the economy especially the financial market and more specifically the stock market. In consonance with the above, a major growth spurring activity within every stock market is the flow of investments in a bid to make capital available within the economy. However, investment is at its best when investors make right decisions irrespective of the vagaries in the market. In a bid to make such decisions, the prices and expected returns on assets are considered together with their accompanying risks, this is the major thrust of the Markowitz model, Capital Asset Pricing Model (CAPM) and the Arbitrage Pricing Theory (APT) as propounded by Markowitz (1959), Sharpe (1964) and Ross (1976) respectively.

Apparently, in a bid to make proper decisions as regards investor's portfolio, the pricing of securities must be considered. Such prices are however a function of risk and other information made available in the market. Meanwhile, as a result of the shortcomings of the two previous models, the Arbitrage Pricing Theory has been considered in literature as more pragmatic approach to asset pricing as authenticated by Chen, Roll and Ross (1986). The concept of arbitrage simply refers to the act of taking overvalued or undervalued securities at high prices in markets that are inefficient with little or no risk attached, making profit from its sales and buying assets which are underpriced as a result (Umoru \& Iweriebor, 2017). As simple as it may sound, this process is influenced by macroeconomic factors that must not be neglected while making such vital investment decisions as the market is not perceived to exist in isolation independent of other macroeconomic factors.

In Nigeria, as a result of the economic recession that hit the global financial markets, investors were in a haste to dispose financial assets held in a bid to exit the market especially in a dynamic world where other investments like real estate are opening up (Abdullahi, 2011). As a result, can this shock exit mean that the APT is valid in the Nigerian Stock Market? Or is there still hope for investment in the stock market considering the macroeconomic factors affecting the returns on securities, much more beyond the reach of market forces in Nigeria? Meanwhile, it is also pertinent to note that validity of the APT has been tested in various markets across the world including Nigeria (Umoru \& Iweribor, 2017; Johansson \& Petersson, 2018; Elshqirat, 2019), however, there still exists absence of consensus as to the validity of the APT in the market especially in Nigeria where Umoru and Iweriebor (2017) as well as Oyetayo and Adeyeye (2017) discovered that it is valid while Monogbe, Edori and Iki (2016) found it to be invalid and inapplicable in the same market. As a result, this study seeks to test for the validity of the APT in Nigeria. This will be done by moving a step further by the way of estimation techniques through the use of the classical Ordinary Least Squares (OLS) to examine the subject matter in the short run, the Auto Regressive Distributed Lag Modelling technique to examine the matter in the long run, the Auto Regressive 
Conditional Heteroskedasticity (ARCH) and Generalized Auto Regressive Conditional Heteroskedasticity $(\mathrm{GARCH})$ to test for the presence of volatility in the market as regards the macroeconomic factors as well as the Engle Granger Causality test to determine the causal effect between macroeconomic factors and stock market returns in Nigeria.

\subsection{LITERATURE REVIEW}

\section{Arbitrage Pricing Theory vs. Capital Asset Pricing Theory}

The APT was postulated by Ross (1976) as an improvement on the Capital Asset Pricing Model (CAPM) as hypothesized by Sharpe (1964) and advanced by Lintner (1965) and Mossin (1966). The CAPM is concerned about the pricing of individual securities which are only influenced by risk free rate, expected return on the security and a constant (Sally, 2011). The CAPM is both loved and criticized for its simplicity as it is easy to calculate but unrealistic in its application. The CAPM was established on the Markowitz model as its foundation, the Markowitz model as propounded by Markowitz (1959) assumes that security holders (investors) are only concerned about the mean and variance of their securities as they are risk averse in nature, hence, portfolio returns with minimal variance are preferred.

Specifically, the CAPM is a simple combination of both risk and return expressed mathematically in a linear form. That is, equilibrium returns on risky portfolio are a function of their covariance with the market portfolio (Sally, 2011). The CAPM assumes that whenever risk free assets exist in a market, the optimal portfolio of every rational investor will be made up of the risk free asset and the market portfolio, meanwhile, such combination in its extent hinges on the risk nature of the investor. The linear equation for the CAPM is stated as:

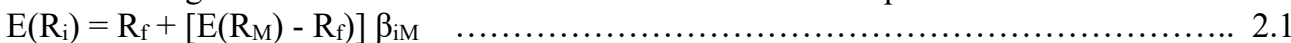

$$
\begin{aligned}
& \text { Where } \mathrm{i} \quad=1 \ldots \ldots . \mathrm{N} \\
& \mathrm{E}\left(\mathrm{R}_{\mathrm{i}}\right) \quad=\text { Expected Return on an asset } \\
& \mathrm{R}_{\mathrm{f}} \quad=\text { Risk free interest rate } \\
& {\left[\mathrm{E}\left(\mathrm{R}_{\mathrm{M}}\right)-\mathrm{R}_{\mathrm{f}}\right) \quad=\text { Risk Premium }} \\
& \beta_{\mathrm{iM}}=\text { Market's Beta which is a measure of the security's future risk }
\end{aligned}
$$

That is, the expected return on any asset is a function of the risk free rate plus the product of the risk premium and the market beta.

According to Oke (2013), the assumptions underlying the CAPM include the notion that the model is a single period model to the end that investors tend to realize maximum utility in a single time period. Also, investors cannot substantially effect changes in the market price irrespective of the bulk of transactions. In addition, the market is perfect and therefore devoid of information asymmetries, transaction costs and taxes. Another assumption lies in the tenet that the expectations of market investors vis-à-vis the returns on assets is identical as their assessments of the probability distribution of expected returns is homogenous in nature. Pandey (2010) also noted that for the CAPM to hold, all investors must borrow and lend at a risk free interest rate. Furthermore, Pandey (2010) summarily extrapolated the implications of the CAPM to include the fact that the portfolio of investors is made up of risky and risk free assets but the risky assets are considered with respect to their market value. Also, investors are compensated for systematic risk which they have no control over, that is, the beta (market risk). The CAPM has been criticized in literature on the grounds of its unrealistic assumptions and the inability to determine specifically determine the Beta.

On the other hand, the APT is predicated on the principle of arbitrage that is, taking advantages of differences in the price in the market to the end that mispriced assets are combined optimally in their portfolio (Pandey, 2010). The mispriced asset which refers to assets that have current price varying from its predicted price is therefore affected by both systematic and unsystematic risk which is not compensated for, factors such as macroeconomic factors principally affect stock returns and this is the kernel of the APT. The theory as formulated by Ross (1976) assumes that return is not just a function of current and future risk within the market but also a predictant of other factors which encompasses the macroeconomic conditions such as inflation, oil price or exchange rate. Suffice to say, the major difference between the CAPM and the APT is the fact that in the APT, returns on asset is affected by varying factors within the economy while in the CAPM, market risk encompasses the factor affecting the returns of any security (Oyetayo \& Adeyeye, 2017).

According to Oyetayo and Adeyeye (2017), the major rationale behind the APT is the desire to make all risky assets within the market not subject to arbitrage condition, that is, the situation whereby an investor makes profit by altering the asset weight in his portfolio assuming risk factors within and beyond the market are static. The APT makes provision for the individual specific portfolio unique to people beyond the market portfolio as held by the CAPM. The theory assumes that in the portfolio of an investor, two securities may likely exist viz; the normal priced and the mispriced asset (either being overpriced or underpriced) to the end that expensive securities can be sold in a short term to buy cheap securities to make maximum profit (Monogbe, Edori \& Iki, 2016). The multi factor APT is built on the assumption that the market is perfectly competitive, there exists presence of homogenous expectations in returns and there is limitless opportunities for buying and selling in the short run to the end that 
returns for sale on the short run are available for re-trading in other assets (Sally, 2011). Although, a major shortcoming of the APT is its inability to propose the specific macroeconomic variables that affect stock returns, however, apostles of the theory such as Chen, Roll and Ross (1986) in a study carried out in the U.S. eventually recommended industrial production, changes in default premium, interest rate spread, inflation rate and changes in real rate of return as underlying macroeconomic factors affecting stock return beyond the reach of the market forces, this has been reinforced by other studies ever since. Mathematically, the APT is expressed below as:

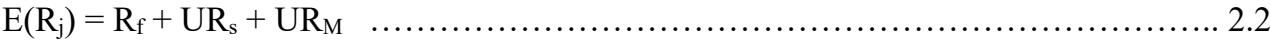

Where $E\left(R_{j}\right) \quad=$ Expected Return on Asset

$R_{f} \quad=$ Risk free interest rate

$\mathrm{UR}_{\mathrm{S}} \quad=$ Risk factors related to the firm

$\mathrm{UR}_{\mathrm{M}} \quad=$ Risk factors related to the macro-economy

Therefore, the expected returns on securities in the market are majorly made up of three components viz; the risk free rate, predictable variations in the market due to information available to the investors as well as unpredictable vagaries in the market as it is caused by forces outside the market (macroeconomic factors). However, as averred by Oloyede (2001), these precise factors are not clearly pinpointed in the APT, nevertheless, the truism and consequently, the role of the theory is still relevant as it is still a subject matter for debate in literature.

Furthermore, it is imperative to consider previous empirical contributions in literature. Consequent on this, Faruque (2011) investigated the validity of the APT in Bangladesh between 1995 and 2010. The study made use of stock returns as the endogenous variables and also used exchange rate, inflation, industrial production index, bank rate, export, money supply and import as exogenous variables. The regression Error Correction Modelling technique was employed for analysis revealing that the presence of the APT is weak in the market as exchange rate was the only macroeconomic variable found to substantially determine stock market returns.

Abdulrahim (2011) examined the relationship between stock returns and macroeconomic variables using the APT model in Nigeria between 2005 and 2010. The study made use of stock returns as the dependent variable while industrial production, interest rate, inflation, exchange rate and money supply were used as independent variables coupled with the use of descriptive statistics and the Error Correction Modelling technique, it was revealed that the APT is valid in Nigeria with special inclination to inflation rate. However, it was recommended that the oil production industry should be developed to ensure an efficient handshake with the capital market.

Uwubanmwen and Obayagbona (2012) tested for validity of the arbitrage pricing theory in the Nigerian stock market between 1985 and 2009. The study employed all share index as the predictant and made use of money supply, index of industrial output, exchange rate and oil price as factor predictors coupled with the use of descriptive statistics and the Vector Error Correction Modelling as the estimating technique, it was revealed that the APT is valid and strongly applicable in Nigeria as oil price was found as a major determining factor of stock returns. Hence, it was recommended that oil price should be properly regulated to boost the stock market.

Monogbe, Edori and Iki (2016) explored the application of the APT in the Nigerian stock market between 1986 and 2014, The study used return on security as the dependent variable and also used interest rate, inflation rate and exchange rate as the independent variable twinned with the use of the Ordinary Least Square as well as the ARCH and GARCH techniques, it was revealed that the APT is not applicable in Nigeria as the factors considered were not significant in explaining the returns on securities. Hence, it was proposed that deviations in macroeconomic variables from targets should be effectively monitored.

In Egypt, Elgiziry and Awad (2017) empirically examined the existence of the APT in the stock market between 2007 and 2013. The study used all share index as the exposed variable and also used industrial production, inflation, money supply, interest rate, discount rate, oil price and exchange rate as exposure variables coupled with the use of factor and regression analysis, it was divulged that oil price has significant influence on stock market implying the validity of the APT in Egypt though with weak applicability as such returns in the market cannot be fully extrapolated by the APT.

Oyetayo and Adeyeye (2017) examined the application of the APT to the capital market in Nigeria between 1985 and 2014. The study made use of all share index as the dependent variable and also used real GDP, treasury bill rate, inflation rate, domestic credit and exchange rate as the independent variables. The study employed the Error Correction Modelling technique as well as the Ordinary Least Squares technique revealing that APT is very relevant to the Nigerian capital market. Hence, it was recommended that local production should be improved to improve stock returns.

Torbira and Agbam (2017) studied the relationship between macroeconomic risk factors and stock returns with special inclination to the APT in Nigeria between 2002 and 2014. The study made use of stock returns as the dependent variable and also used market capitalization, lending rate, deposit rate, interest rate spread, inflation rate, exchange rate, oil price and treasury bill rate as independent variables coupled with the use of descriptive statistics and the Error Correction modelling technique, it was revealed that the APT is evidently valid in the Nigerian capital market. Hence, investors should adopt hedging methods in managing their portfolio.

Umoru and Iweriebor (2017) empirically tested the validity of the APT and its volatility in the Nigerian stock 
market between 2010 and 2014. The study made use of stock market returns as the predictant and also used treasury bill rate, inflation rate, industrial production and growth rate of broad money as the predictors coupled with the use of Generalized Least Squares as well as the ARCH and GARCH techniques, it was revealed that the APT is valid in Nigeria although there exists detrimental market volatility in Nigeria. Hence, it was recommended that macroeconomic factors should not be downplayed in the process of investing in the market.

French (2017) examined the presence of the APT in the USA and the five ASEAN countries viz; Singapore, Thailand, Philippines, Malaysia and Indonesia between 2012 and 2016. The study used stock returns as the dependent variable and also used inflation rate, treasury bill rate, bond rate, industrial production, risk premium, term structure and exchange rate as independent variables coupled with the use of Pooled OLS, it was discovered that the APT is a weak pricing tool in the market.

Johansson and Petersson (2018) examined the applicability of the APT in Swedish market between 2002 and 2017. The study used return on securities as the determined variable and also made use of inflation, oil price, exchange rate to both the dollar and Euro, copper price, gold spot price, export, import, GDP of both the US and Germany as determining variables. The study made use of the Error Correction Modelling technique

Elshqirat (2019) investigated the presence of the APT in the capital market of Jordan considering data for 100 quoted firms between 2000 and 2016. The study used stock return as the dependent variable and also used unemployment rate, GDP, Industrial production index as well as exports as the independent variables coupled with the use of descriptive statistics and multiple regression analysis, it was revealed that the presence of the APT is weak in the Jordanian market.

\subsection{ESTIMATION MATERIALS AND METHODS}

The study made use of the times series data from the CBN statistical bulletin and the National Bureau of Statistics from 1986 to 2018. The data were first analysed using the Ordinary Least Square (OLS) technique for the short run analysis, then, the Augmented Dickey-Fuller Unit Root Test was used to test for the stationarity of data and then, the order of integration to guide the selection of the Auto Regressive Distributed Lag (ARDL) technique which will determine the long run analysis underlying the validity of the APT. Also, the ARCH and GARCH technique was used to examine the presence of volatility persistence and clustering in the model. In addition, the study applied the Engle Granger causality technique to examine the causal relationship between macroeconomic variables and stock returns.

\section{Model Specification}

The model adapted for the study was the model used by Oyetayo and Adeyeye (2017). This study deviates from their study by the inclusion of some other macroeconomic variables as well as tools of analysis such as the ARCH and GARCH and the Causality test not captured in their study. The model for this study is therefore specified as: $A S I=f(O I L P, E X G R, I N F R, I N T R, I N D Q, R G D P)$

From equation 3.1, it can further be stated in more explicit form as:

$A S I=f\left(\beta_{0}+\beta_{1} O I L P+\beta_{2} E X G R+\beta_{3} I N F R+\beta_{4} I N T R+\beta_{5} I N D Q+\beta_{6} R G D P+\mu\right) \ldots 3.2$

Where:

ASI

OILP

EXGR

$I N F R$

$I N T R$

$I N D Q$

$R G D P$

$\mu$

$\beta_{0}, \beta_{1}, \beta_{2}, \beta_{3}, \beta_{4}, \beta_{5}$ and,$\beta_{6}=$
All Share Index

Oil Price

Exchange Rate

Inflation Rate

Interest Rate

Industrial Output

Real Gross Domestic Product

Error term

Coefficients of the Estimates 


\subsection{RESULTS AND DISCUSSIONS}

Table 4.1: Ordinary Least Square Results

Dependent Variable: ASI

\begin{tabular}{|l|l|l|l|l|}
\hline Variable & Co-Efficient & Std. Error & T-Statistics & Prob. \\
\hline OILP & -0.408263 & 0.246498 & -1.656254 & 0.1097 \\
\hline EXGR & 0.189165 & 0.255354 & 0.740793 & 0.4655 \\
\hline INFL & -0.181000 & 0.137569 & -1.315701 & 0.1998 \\
\hline INTR & 0.164821 & 0.339060 & 0.486113 & 0.6310 \\
\hline INDQ & 1.441179 & 0.662970 & 2.173823 & 0.0390 \\
\hline RGDP & -0.469621 & 0.578328 & -0.812033 & 0.4241 \\
\hline C & 5.345432 & 1.507494 & 3.545907 & 0.0015 \\
\hline R-Squared & 0.948237 & & & \\
Prob. F(Stat) & 0.000000 & & & \\
D-W Stat. & 0.470965 & & & \\
\hline
\end{tabular}

Source: Author's Computation (2020)

The short run oriented result as seen in the table 4.1 above shows that the presence of the APT in the Nigerian stock market is considerably valid as the only macroeconomic variable that affects stock returns due to its significance is the industrial output in the short run. This is in line with the discovery of Chen, Roll and Ross (1986) in the USA as at the time of the empirical authentication of the APT.

Table 4.2: Augmented Dickey Fuller (ADF) Unit Root Test

\begin{tabular}{lllll}
\hline Variables & \multicolumn{2}{c}{ ADF } & Order of integration \\
\cline { 2 - 4 } & Critical values @5\% & t- statistics & Prob. & \\
\hline ASI & -2.960411 & -3.821327 & 0.0067 & $\mathrm{I}(1)$ \\
OILP & -2.960411 & -4.977115 & 0.0003 & $\mathrm{I}(1)$ \\
EXGR & -2.960411 & -5.655163 & 0.0001 & $\mathrm{I}(1)$ \\
INFL & -2.957110 & -2.997481 & 0.0458 & $\mathrm{I}(0)$ \\
INTR & -2.963972 & -5.490232 & 0.0001 & $\mathrm{I}(1)$ \\
INDQ & -2.963972 & -4.248219 & 0.0024 & $\mathrm{I}(1)$ \\
RGDP & -2.957110 & -3.720387 & 0.0085 & $\mathrm{I}(0)$ \\
\hline
\end{tabular}

Source: Author's Computation (2020)

The ADF URT test as shown in the table 4.2 revealed that data for all variables were stationary at first difference except inflation and real GDP which was stationary at level. Therefore, the mixed order of integration therefore necessitates the use of the Auto Regressive Distributed Lag Modelling technique to estimate the long run effect. However, there is need to determine the appropriate lags necessary for the ARDL model and this was done using the Vector Auto Regressive (VAR) optimal lag length criteria.

\section{Table 4.3: Selection of Optimal Lag Length}

\begin{tabular}{|c|c|c|c|c|c|c|}
\hline Lag & LogL & LR & FPE & AIC & SC & HQ \\
\hline 0 & -110.7864 & NA & $4.71 \mathrm{e}-06$ & 7.599124 & 7.922927 & 7.704675 \\
\hline 1 & 94.04667 & 303.9459 & $2.20 \mathrm{e}-10$ & -2.454624 & $0.135805^{*}$ & -1.610209 \\
\hline 2 & 171.8155 & $80.27756^{*}$ & $5.88 \mathrm{e}-11^{*}$ & $-4.310681^{*}$ & 0.546373 & $-2.727402^{*}$ \\
\hline
\end{tabular}

Source: Author's Computation (2020)

From Table 4.3, the number of lags suitable for ARDL model is 2. This is however considered when ARDL co-integration and causality test were carried out.

Table 4.4: ARDL Bounds Test (Co-Integration Result)

\begin{tabular}{lcc}
\hline F-Statistics & Lower Bound (5\%) & Upper Bound (5\%) \\
\hline 3.854544 & 2.45 & 3.61 \\
\hline
\end{tabular}

Source: Author's Computation (2020)

The table 4.4 revealed that the F-statistics greater than the upper bound at $5 \%$ significance level shows that there exists a long run relationship among the variables. 
Table 4.5: ARDL Long Run Result

Dependent Variable: ASI

\begin{tabular}{|c|r|r|r|r|}
\hline Variable & Co-Efficient & Std. Error & T-Statistics & Prob. \\
\hline OILP & -0.584506 & 0.282657 & -2.067896 & 0.0552 \\
\hline EXGR & 0.225142 & 0.435963 & 0.516424 & 0.6126 \\
\hline INFL & -0.893633 & 0.264113 & -3.383530 & 0.0038 \\
\hline INTR & 0.082545 & 0.338716 & 0.243700 & 0.8106 \\
\hline INDQ & 1.193984 & 1.032611 & 1.156277 & 0.2645 \\
\hline RGDP & -0.398034 & 1.161483 & -0.342694 & 0.7363 \\
\hline C & 8.688981 & 2.334055 & 3.722697 & 0.0019 \\
\hline
\end{tabular}

Source: Author's Computation (2020)

The table 4.5 which showed the long run ARDL revealed that the APT is also considerably valid in Nigeria as inflation was found as the macroeconomic factor which affects stock returns in the long run.

Diagnostic Tests

Table 4.6: ARDL Diagnostic Estimations

\begin{tabular}{lll}
\hline Test Statistic & F-statistic & P-value \\
\hline Breusch-Godfrey Serial Correlation LM Test & 0.682232 & 0.5215 \\
Breusch-Godfrey Heteroscedasticity Test & 1.182528 & 0.3705 \\
Jarque-Bera (JB) Normality Test & 0.143617 & 0.9307 \\
\hline
\end{tabular}

Source: Author's Computation (2020)

Table 4.6 shows the diagnostic tests carried out to determine the reliability of the ARDL model. These tests include LM serial correlation, heteroscedasticity and normality test. From the three diagnostics conducted, it is clearly indicated that there is no serial correlation and heteroscedasticity and the variables are normally distributed. This is evident from the result of the F-statistic and their accompanying probability values which are higher at 5\% value in all the tests.

Granger Causality Test

Table 4.6: Granger Causality Test

\begin{tabular}{|c|c|c|c|}
\hline OILP does not Granger Cause ASI & 31 & 0.17953 & 0.8367 \\
\hline ASI does not Granger Cause OILP & & 1.74902 & 0.1938 \\
\hline EXGR does not Granger Cause ASI & 31 & 5.50809 & 0.0101 \\
\hline ASI does not Granger Cause EXGR & & 3.70124 & 0.0385 \\
\hline INFL does not Granger Cause ASI & 31 & 1.72721 & 0.1976 \\
\hline ASI does not Granger Cause INFL & & 5.08403 & 0.0137 \\
\hline INTR does not Granger Cause ASI & 31 & 0.72565 & 0.4936 \\
\hline ASI does not Granger Cause INTR & & 7.23338 & 0.0032 \\
\hline INDQ does not Granger Cause ASI & 31 & 0.93695 & 0.4047 \\
\hline ASI does not Granger Cause INDQ & & 1.16182 & 0.3286 \\
\hline RGDP does not Granger Cause ASI & 31 & 2.72131 & 0.0845 \\
\hline ASI does not Granger Cause RGDP & & 0.14631 & 0.8646 \\
\hline
\end{tabular}

Source: Author's Computation (2020)

Table 4.6 shows the casual relationship between the variables. Therefore, considering such causal relationship, it can be discovered that the APT is valid in the market as macroeconomic variables such as inflation and interest rates cause stock returns while a bidirectional causality exists between exchange rate and stock returns. 
Table 4.7: Results of ARCH and GARCH Model for Macroeconomic Volatility on Stock Returns

\begin{tabular}{|l|l|l|l|}
\hline Mean Equation & Coefficient & Z-statistic & Probability \\
\hline Variable & -0.379300 & -2.802608 & 0.0051 \\
\hline OILP & -0.535649 & -10.32184 & 0.0000 \\
\hline EXGR & -0.111652 & -1.916828 & 0.0553 \\
\hline INFL & 0.651978 & 4.194930 & 0.0000 \\
\hline INTR & 1.109810 & 394.1886 & 0.0000 \\
\hline INDQ & 0.594786 & 637.9297 & 0.0000 \\
\hline RGDP & -0.004538 & -1.638379 & 0.1013 \\
\hline Variance Equation & -0.162924 & -1.033628 & 0.3013 \\
\hline C & 1.501286 & 198.4958 & 0.0000 \\
\hline RESID(-1)^2 & \multicolumn{2}{|l|}{} \\
\hline GARCH(-1) &
\end{tabular}

Source: Author's Computation (2020)

Table 4.7 presents the volatility analysis result through the use of the ARCH and GARCH modeling technique. The result revealed that the addition of the ARCH $\left(\operatorname{RESID}(-1)^{\wedge} 2\right)$ and $\operatorname{GARCH}(-1)$ coefficients is one which implies the presence of high volatility in macroeconomic factors on stock returns. Also, the ARCH effect revealed that there is no volatility clustering that is, the magnitude of volatility is not always followed by same magnitude in subsequent years while the GARCH effect revealed that there exists volatility persistence in the macroeconomic variables.

\section{Discussion of Findings and Implications}

This study examined the validity of the arbitrage pricing model and the presence of volatility in the macroeconomic environment as it affects stock returns. The Ordinary Least Square was employed to examine the subject matter in the short run. It was revealed that industrial output has positive effect on stock returns while other variables exert no significant effect on stock returns in the short run. This is in line with the findings of Chen, Roll and Ross (1986) which is the first empirical authentication of the theory. This implies that the APT is valid in the short run but to considerable extent. Also, it can be deduced that an increase in industrial output will definitely lead to an increase in stock returns in the short run. This is probable in Nigeria most of the capital mobilized in the stock market is rechanneled for manufacturing and industrial production purpose by such large scale industries in need. Hence, the performance of the industrial output with respect to the capital mobilized for them will have a long way to go in determining the returns accruing to the investors even in the short run.

Also, the Auto Regressive Distributed Lag Modelling (ARDL) technique was used to examine the subject matter in the long run. The ARDL bounds test revealed that macroeconomic variables have a long run relationship with stock returns. The ARDL eventually revealed that inflation has negative effect on stock returns while other variables exert no significant effect on stock returns. This implies that an increase in inflation will reduce stock returns, this is probable as excessive inflation reduces the real value of money in the long run to the end that returns realized tomorrow on an investment made today falls below expectation. This is line with the findings of Torbira and Agbam (2017). In addition, the Granger causality test revealed that a bidirectional causal relationship exists between exchange rate and stock returns while a unidirectional causality runs from inflation rate and interest rate to stock returns. This implies that a change in the behavior of exchange, inflation and interest rates will definitely produce a change in the behavior of stock returns while a change in behavior of stock returns will definitely produce a change in the behavior of exchange rate. This is probable as these three macroeconomic rates are the major information criteria that determines investment in the stock market as well as the return emanating from the market. Meanwhile, investments within the market relative to other markets across the globe has a part to play in fixing the rate of exchange between such nations at the same time. Also, the ARCH and GARCH analysis revealed that there exists high volatility with persistence but without clustering in the macroeconomic environment as it affects stock returns. This is probable as Nigeria has experienced several regimes in regulating its economic and financial environment right from the highly regulated regimes to the lazziez faire period, thus leading to consistent and persistent fluctuations in the trend of the rates. However, the clustering is not without possibility often times, periods of fluctuations are always followed by periods of relative stability.

\subsection{CONCLUSION AND RECOMMENDATIONS}

The focus of the study is to test for the validity of the Arbitrage Pricing Theory and the presence of volatility in the Nigerian Stock Market. To this end, the study adopted various econometric tools of analysis viz; the ordinary least square, ARDL, causality test and the ARCH and GARCH techniques revealing that the APT is valid in the Nigerian market both in the short run and the long run as industrial output and inflation rate exerted positive effect and negative effect on stock returns in the short and long run respectively. In addition, the test for volatility revealed 
that there is presence of high and persistent volatility in the stock market while the causality test revealed that there is a unidirectional causality running from inflation and interest rates to stock returns while a bi-directional relationship exists between exchange rate and stock returns. Hence, it was recommended that short term investors should pay more attention to the industrial output before investing as they should diversify their portfolio to accommodate other sectors of the economy such as agriculture in times when the industrial sector is nose-diving to realize substantial returns. Also, the government should adopt policies such as substantial tax reliefs, grants and import substitution strategies to boost industrial output to ensure substantial stock returns in the short run. Invariably, such attempt to boost industrial output will increase competition and efficiency and reduce cost in the economy, coupled with other strategies such as floor and ceilings of macroeconomic rates, inflation will be reduced and become relatively stable to keep stock returns attractive.

\section{List of Abbreviations}

APT: Arbitrage Pricing Theory; ARDL: Auto Regressive Distributed Lag; ARCH: Auto Regressive Conditional Heteroscedasticity; GARCH: Generalized Auto Regressive Conditional Heteroscedasticity; CAPM: Capital Asset Pricing Model; OLS: Ordinary Least Squares; CBN: Central Bank of Nigeria; VAR: vector Auto Regressive; GDP: Gross Domestic Product; ADF URT: Augmented Dickey Fuller Unit Root Test; ASI: All Share Index; OILP; Oil Price; EXGR; Exchange Rate; INFR: Inflation Rate; INTR: Interest Rate; INDQ: Industrial Output; RGDP; Real Gross Domestic Product

\section{Availability of Data and Materials}

All data generated and analysed for all countries considered during the study are publicly available in the CBN Statistical Bulletin and can be assessed at https://www.cbn.gov.ng/documents/statbulletin.asp.

\section{Competing Interests}

The authors declare that they have no competing interests.

\section{Funding}

All authors declare that they have not obtained any extra funding beyond their regular remuneration from the institutions for which they work.

\section{Authors' Contributions}

All authors contributed to the concept of the manuscript. JO and FT monitored the gathering of data for the analysis, SO handled the review of literature and problem, KM analysed the data. The authors read and approved the final manuscript.

\section{Acknowledgements}

The authors gratefully acknowledge the support of Omoloye Najeem Adekunle for his comments and suggestions. Authors' Information

$1,2,3 \& 4$ Department of Finance, Ekiti State University, Nigeria

\section{References}

Abdullahi, I. B. (2011). Sectorial Analysis of Risks and Returns of the Quoted Firms in the Nigerian Capital Market. (Ph.D. Thesis). University of Ilorin, Nigeria.

Abdulrahim, S. S. (2011). Nigerian Stock Returns and Macroeconomic Variables: Evidence from the APT Model. (M.Sc. Thesis). Eastern Mediterranean University, North Cyprus. Accessed November 2020 at https://pdfs.semanticscholar.org/040a/97339adf60cfb565920e9dd78300ab032780.pdf.

Chen, L., Roll, R., \& Ross, S. (1986). Economic Forces and the Stock Market. Journal of Business, 56(1), 383403. https://rady.ucsd.edu/faculty/directory/valkanov/pub/classes/mfe/docs/ChenRollRoss JB 1986.pdf.

Elgiziry, K. A. M., \& Awad, M. M. (2017). Test of the Arbitrage Pricing Theory in the Egyptian Stock Exchange. Journal of Behavioral Economics, Finance, Entrepreneurship, Accounting and Transport, 5(4), 30-38. Accessed

November 2020 https://www.academia.edu/36205929/Test_of the_Arbitrage_Pricing_Theory_in the_Egyptian_Stock_Exc hange

Elshqirat, M. K. (2019). An Empirical Examination of the Arbitrage Pricing Theory: Evidence from Jordan. Journal of Studies in Social Sciences, 18(2), 46-67. Accessed November 2020 at https://infinitypress.info/index.php/jsss/article/download/1832/714

Faruque, M. U. (2011). An Empirical Investigation of the Arbitrage Pricing Theory in a Frontier Stock Market: Evidence from Bangladesh. MPRA Paper Series. Accessed November 2020 at http://mpra.ub.unimuenchen.de/38675/.

French, J. (2017). Macroeconomic Forces and Arbitrage Pricing Theory. Journal of Comparative Asian Development, 16(1), 1-20. Doi: https://doi.org/10.1080/15339114.2017.1297245

Lintner, J. (1965). The Valuation of Risk Assets and Selection of Risky Investments in Stock Portfolios and Capital 
Budgets. Review of Economics and Statistics, 47(1), 13-37. Doi: https://doi.org/10.2307/1924119

Markowitz, H. (1959). Portfolio Selection: Efficient Diversification of Investments. New York: Wiley \& Sons Inc. Accessed November 2020 at https://cowles.yale.edu/sites/default/files/files/pub/mon/m16-all.pdf

Monogbe, T. G., Edori, I. S., \& Iki, B. A. (2016). The Application of Arbitrage Pricing Theory (APT) in Nigeria Capital Market. International Journal of Banking and Finance Research, 2(1), 32-45. Accessed November 2020 https://iiardpub.org/get/IJBFR/VOL.\%202\%20NO.\%201\%202016/THE\%20APPLICATION\%20OF\%20A RBITRAGE.pdf

Mossin, J. (1966). Equilibrium in a Capital Asset Market. Econometrica, 34(2), 768-783. Doi: https://doi.org/10.2307/1910098

Oke, B. O. (2013). Capital Asset Pricing Model (CAPM): Evidence from Nigeria. Research Journal of Finance and Accounting, 4(9), 17-26. Accessed November 2020 at https://www.iiste.org/Journals/index.php/RJFA/article/view/6705

Oloyede, J. A. (2001). Fundamentals of Investment Analysis. Lagos: Lion Press.

Oyetayo, O. J., \& Adeyeye, P. O. (2017). A Robust Application of the Arbitrage Pricing Theory: Evidence from Nigeria. Journal of Economics and Behavioral Studies, 9(1), 141-151. Accessed November 2020 at https://ideas.repec.org/a/rnd/arjebs/v9y2017i1p141-151.html

Pandey, I. M. (2010). Financial Management. New Delhi: Vikas Publishing House PVT Ltd. Available at https://www.amazon.com/Financial-Management-10Th-I-M-Pandey/dp/8125937145

Ross, S. (1976). The Arbitrage Theory of Capital Asset Pricing. Journal of Economic Theory, 13(1), 314-360. Accessed November 2020 at https://www.top1000funds.com/wp-content/uploads/2014/05/The-ArbitrageTheory-of-Capital-Asset-Pricing.pdf

Sally, S. A. (2011). Nigerian Stock Returns and Macroeconomic Variables: Evidence from the APT Model. (M.Sc. Thesis). Eastern Mediterranean University, Cyprus.

Sharpe, W. F. (1964). Capital Asset Prices: A Theory of Market Equilibrium under Conditions of Risk. Journal of Finance, 19(3), 425-442. Doi: https://doi.org/10.1111/j.1540-6261.1964.tb02865.x

Torbira, L. L., \& Agbam, A. S. (2017). Macroeconomic Risk factors and Stock Returns: The Arbitrage Pricing Approach. Journal of Finance, Banking and Investment, 4(1), 41-71. Accessed November 2020 at http://absudbfjournals.com/wp-content/uploads/2017/05/3.-Macroeconomic-Risk-Factors-and-StockReturns.pdf

Umoru, D., \& Iweriebor, S. (2017). Econometrics Test of Arbitrage Pricing and its Volatility in the Nigerian Equities Market. International Journal of Management Studies, Business and Entrepreneurship Research, 2(2), Accessed November 2020 https://www.edouniversity.edu.ng/oerrepository/articles/econometrics_test_of_arbitrage_pricing_and_its_v olatility_in_the_nigerian_equities_market.pdf

Uwubanmwen, A. E., \& Obayagbona, J. (2012). Tests of the Arbitrage Pricing Theory Using Macroeconomic Variables in the Nigerian Stock Market. Ethiopian Journal of Economics, 11(1), 1-18. Accessed November 2020 at https://www.ajol.info/index.php/eje/article/view/91563 